\title{
Ice nucleation on mineral dust particles: Onset conditions, nucleation rates and contact angles
}

\author{
Michael L. Eastwood, ${ }^{1}$ Sebastien Cremel, ${ }^{1}$ Clemens Gehrke, ${ }^{1}$ Eric Girard, ${ }^{2}$ \\ and Allan K. Bertram ${ }^{1}$ \\ Received 20 June 2008; revised 4 September 2008; accepted 18 September 2008; published 20 November 2008.
}

[1] An optical microscope coupled to a flow cell was used to investigate the onset conditions for ice nucleation on five atmospherically relevant minerals at temperatures ranging from 233 to $246 \mathrm{~K}$. Here we define the onset conditions as the humidity and temperature at which the first ice nucleation event was observed. Kaolinite and muscovite were found to be efficient ice nuclei in the deposition mode, requiring relative humidities with respect to ice $\left(\mathrm{RH}_{\mathrm{i}}\right)$ below $112 \%$ in order to initiate ice crystal formation. Quartz and calcite, by contrast, were poor ice nuclei, requiring relative humidities close to water saturation before ice crystals would form. Montmorillonite particles were efficient ice nuclei at temperatures below $241 \mathrm{~K}$ but were poor ice nuclei at higher temperatures. In several cases, there was a lack of quantitative agreement between our data and previously published work. This can be explained by several factors including the mineral source, the particle sizes, the surface area available for nucleation, and observation time. Heterogeneous nucleation rates $\left(J_{\text {het }}\right)$ were calculated from the measurements of the onset conditions (temperature and $\mathrm{RH}_{\mathrm{i}}$ ) required from ice nucleation. The $J_{\text {het }}$ values were then used to calculate contact angles $(\theta)$ between the mineral substrates and an ice embryo using classical nucleation theory. The contact angles measured for kaolinite and muscovite ranged from $6^{\circ}$ to $12^{\circ}$, whereas for quartz and calcite, the contact angles ranged from $25^{\circ}$ to $27^{\circ}$. The reported $J_{\text {het }}$ and $\theta$ values may allow for a more direct comparison between laboratory studies and can be used when modeling ice cloud formation in the atmosphere.

Citation: Eastwood, M. L., S. Cremel, C. Gehrke, E. Girard, and A. K. Bertram (2008), Ice nucleation on mineral dust particles: Onset conditions, nucleation rates and contact angles, J. Geophys. Res., 113, D22203, doi:10.1029/2008JD010639.

\section{Introduction}

[2] Ice nucleation can occur in the atmosphere by either homogeneous nucleation or heterogeneous nucleation. Heterogeneous nucleation typically involves solid substrates, which are often called ice nuclei (IN). These ice nuclei have the potential to modify climate by changing the formation conditions and properties of ice and mixed-phase clouds. [Kärcher, 2004; Haag and Kärcher, 2004; Lohmann and Feichter, 2005; Lohmann and Diehl, 2006]. Our lack of knowledge on ice nucleation is a major obstacle for the simulation of the complex interactions between aerosols and cold clouds. It has been shown in various investigations that mixed-phase clouds often cannot be properly simulated with the existing IN parameterizations, such as those of Fletcher [1962] and Meyers et al. [1992] [Girard and Curry, 2001; Girard et al., 2005]. More physically based parameteriza-

\footnotetext{
${ }^{1}$ Department of Chemistry, University of British Columbia, Vancouver, British Columbia, Canada.

${ }^{2}$ Department of Earth and Atmospheric Sciences, University of Quebec at Montreal, Montreal, Quebec, Canada.

Copyright 2008 by the American Geophysical Union. 0148-0227/08/2008JD010639\$09.00
}

tions are needed to simulate heterogeneous nucleation in climate models.

[3] Mineral dust particles are abundant in the atmosphere, and both laboratory [Pruppacher and Klett, 1997; Bailey and Hallett, 2002; DeMott, 2002; Zuberi et al., 2002; Hung et al., 2003; Archuleta et al., 2005; Mangold et al., 2005; Möhler et al., 2006; Field et al., 2006; Kanji and Abbatt, 2006; Knopf and Koop, 2006; Marcolli et al., 2007; Zimmerman et al., 2007] and field measurements [Sassen, 2002, 2005; DeMott et al., 2003a, 2003b; Sassen et al., 2003; Toon, 2003; Cziczo et al., 2004; Twohy and Poellot, 2005; Kanji and Abbatt, 2006] have shown that mineral dust particles are effective ice nuclei. Laboratory data have shown that mineral dust particles can lower the supersaturations required for ice formation compared to homogeneous nucleation. At the same time, field measurements have shown that mineral dust particles can have a significant impact on cloud formation, cloud properties and precipitation [Sassen, 2002, 2005; DeMott et al., 2003a; Sassen et al., 2003]. Measurements have also shown that the cores of ice crystals often contain mineral dust particles, suggesting that ice nucleation is often initiated by mineral dust aerosols in the atmosphere [Heintzenberg et al., 1996; Cziczo et al., 2004; Twohy and Poellot, 2005]. Furthermore, 
Table 1. Mineralogy of Saharan Dust Collected at Sal Island (in the Cape Verde Islands), Barabados, and Miami, Florida, After Three Large Saharan Dust Outbreaks [Glaccum and Prospero, $1980]^{\mathrm{a}}$

\begin{tabular}{lccc}
\hline \multicolumn{1}{c}{ Mineral } & $\begin{array}{c}\text { Sal Island } \\
(\%)\end{array}$ & $\begin{array}{c}\text { Barbados } \\
(\%)\end{array}$ & $\begin{array}{c}\text { Miami } \\
(\%)\end{array}$ \\
\hline Mica & 53.8 & 64.3 & 62.1 \\
Kaolinite & 6.6 & 8.3 & 7.1 \\
Chlorite & 4.3 & 4.1 & 4.2 \\
Quartz & 19.6 & 13.8 & 14.2 \\
Microcline & 2.2 & 1.5 & 1.1 \\
Plagioclase & 5.4 & 4.1 & 4.5 \\
Calcite & 8.2 & 3.9 & 6.9 \\
Montmorillonite & $\leq 5$ & $\leq 5$ & $\leq 5$ \\
\hline
\end{tabular}

${ }^{\text {a }}$ Percentages shown are averages of the three outbreaks (assuming 100\% crystalline material).

measurements of the chemical composition of ice nuclei in the atmosphere show that mineral dust is composed of a significant fraction of atmospheric IN [Chen et al., 1998; Rogers et al., 2001; DeMott et al., 2003b; Richardson et al., 2007].

[4] Although there have been numerous studies on the ice nucleating properties of mineral dust particles, more work is still needed for a complete understanding of the ice nucleation properties of these particles [Vali, 1996; Martin, 2000; Demott, 2002; Cantrell and Heymsfield, 2005]. For example, only a few of the most abundant types of minerals found in the atmosphere have been studied in detail. In addition, in many of the previous studies, only the onset conditions for ice nucleation were reported and only a few studies considered ice nucleation rates (a key parameter for describing ice nucleation). Measurements of ice nucleation rates are needed to more accurately compare laboratory results and to extrapolate laboratory data to the atmosphere and for climate modeling.

[5] Our studies focus on the ice nucleating properties of mineral dust particles at temperatures between 247 and 233 $\mathrm{K}$, a temperature range relevant for the lower troposphere. As pointed out by Vali [1996] in a review on ice nucleation, the origin of ice in lower tropospheric clouds is not resolved, and it remains a question of great importance and in need of new efforts. Also, there have been very few measurements in the range of 247 to $233 \mathrm{~K}$. In the following study we focus on the ice nucleation properties of muscovite (a mineral in the mica group), kaolinite, montmorillonite, quartz and calcite particles. These minerals were chosen since they are major components of aerosolized mineral dust found in the atmosphere. To illustrate this point, the mineralogies of Saharan dust collected in Sal Island, Barbados and Miami after three large Saharan dust outbreaks are shown in Table 1 [Glaccum and Prospero, 1980]. The minerals chosen for our studies represent over $90 \%$ of the total mass during these outbreaks. Montmorillonite compo-

Table 2. Chemical Formulae of the Five Minerals Studied [Anthony et al., 1995]

\begin{tabular}{|c|c|}
\hline Mineral & Formula \\
\hline $\begin{array}{l}\text { Muscovite } \\
\text { Kaolinite } \\
\text { Quartz } \\
\text { Calcite } \\
\text { Montmorillonite } \\
\end{array}$ & $\begin{array}{c}\mathrm{KAl}_{2}\left(\mathrm{Si}_{3} \mathrm{Al}\right) \mathrm{O}_{10}(\mathrm{OH}, \mathrm{F})_{2} \\
\mathrm{Al}_{4} \mathrm{Si}_{4} \mathrm{O}_{10}(\mathrm{OH})_{8} \\
\mathrm{SiO}_{2} \\
\mathrm{CaCO}_{3} \\
(\mathrm{Na}, \mathrm{Ca})_{0.3}(\mathrm{Al}, \mathrm{Mg})_{2} \mathrm{Si}_{4} \mathrm{O}_{10}(\mathrm{OH})_{2} \quad \mathrm{nH}_{2} \mathrm{O} \\
\end{array}$ \\
\hline
\end{tabular}

sition was below the detection limit $(5 \%)$ in the Saharan dust studies illustrated in Table 1 , but several studies have cited montmorillonite as one of the dominant clay minerals present in African and Asian dusts [Prospero, 1999; Hanisch and Crowley, 2001].

[6] This paper is organized as follows: first, we present measurements of the onset conditions for ice nucleation on muscovite, kaolinite, montmorillonite, quartz and calcite. Here we define the onset conditions as the humidity and temperature at which the first ice nucleation event was observed. Second, we compare this data with existing data in the literature. Third, from the onset conditions we determine heterogeneous ice nucleation rates (number of nucleation events per unit surface area of solid material per unit time) for each mineral type. Fourth, we parameterized the heterogeneous nucleation rates using classical nucleation theory. Classical nucleation theory is a reasonable starting point for analyzing laboratory data, as this theory has been used in the past for describing ice nucleation in atmospheric models [Kärcher, 1996, 1998; Jensen and Toon, 1997; Jensen et al., 1998; Kärcher et al., 1998; Martin, 2000; Demott, 2002; Morrison et al., 2005]. In this last step we determined the contact angle between an ice nucleus and the mineral surfaces.

\section{Experimental}

[7] Micron-sized muscovite particles were generated by grinding muscovite flakes $(1-10 \mathrm{~mm}$ in diameter, $<1 \mathrm{~mm}$ in thickness, purchased from Alfa Aesar), and micron-sized quartz particles were produced by grinding a sample of quartz tubing (purchased from United Silica). Kaolinite (purchased from Fluka), montmorillonite K10 (purchased from Fluka) and calcite (purchased from Puratronic ${ }^{\circledR}$, Alfa Aesar) particles were used as supplied. Table 2 lists the chemical formulae of the minerals studied.

[8] The apparatus used in these studies consisted of an optical microscope coupled to a flow cell (see Figure 1) in which the humidity and temperature could be accurately controlled [Dymarska et al., 2006; Parsons et al., 2004a, 2004b]. Mineral dust particles were deposited on the bottom surface of the flow cell; the relative humidity with respect to ice $\left(\mathrm{RH}_{\mathrm{i}}\right)$ inside the cell was increased, and the conditions under which ice crystals formed were determined with a reflected-light microscope (Zeiss Axiotech 100) equipped with a $10 \times$ objective lens. From these measurements we determine the onset conditions (temperature and relative humidity) for ice nucleation.

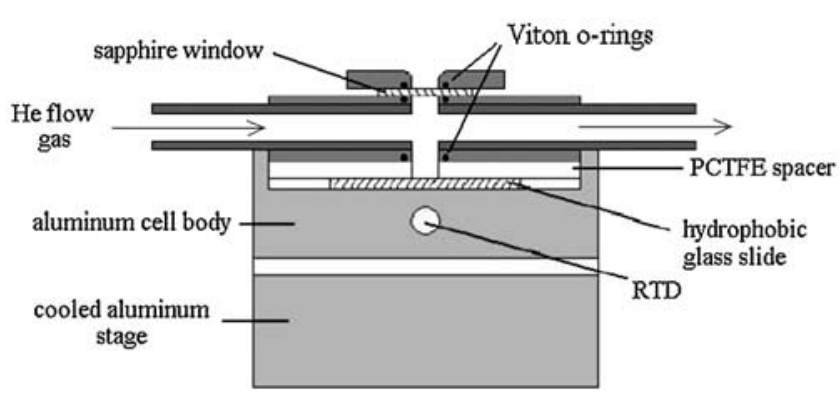

Figure 1. Schematic of the flow cell used for this study. 
[9] The temperature of the cooling stage and hence the flow cell was regulated with a refrigerating circulator (Thermo Neslab ULT-95). A hydrophobic slide (which supported the particles) was positioned inside the aluminum cell body. An insulating spacer, made from polychlorotrifluoroethylene (PCTFE), was placed between the hydrophobic glass slide and the flow cell body. This ensured that the coldest portion of the flow cell was the glass substrate (by $\sim 10 \mathrm{~K}$ ), thus preventing unwanted ice nucleation on other components of the cell. All seals within the cell were made with Viton O-rings with the exception of the seal between the glass slide and the PCTFE spacer, which was made with low vapor pressure chlorotrifluoroethylene grease (Series 28LT from Halocarbon Products, vapor pressure $<0.1$ Torr at $293 \mathrm{~K}$ ). The grease ensured that no space remained between the glass slide and the PCTFE spacer, where ice could nucleate without being detected by the microscope. For kaolinite and montmorillonite we also performed experiments using a lower vapor pressure grease (Krytox LVP from DuPont, vapor pressure $<10^{-13}$ Torr at $293 \mathrm{~K}$ ) and the same results were obtained. Also, for kaolinite we previously carried out experiments without grease and the same results were obtained, suggesting the grease had little effect on the freezing results [Dymarska et al., 2006].

[10] The upper portion of the cell body and the inlet and outlet were made from stainless steel. A sapphire window (1 $\mathrm{mm}$ thick) was positioned at the top of the cell body, allowing optical access to the bottom surface of the cell. The reflected-light microscope was coupled to a highresolution monochrome digital video camera (Sony, XCD$\mathrm{X} 700$ ) which captured images of the particles deposited on the hydrophobic slide during the course of the experiments. The images were analyzed with the Northern Eclipse software package to determine particle size and total surface area available for ice nucleation.

[11] The bottom surface of the flow cell was a hydrophobic slide made from a glass cover slide treated with dichlorodimethylsilane (DCDMS). This hydrophobic layer was added to reduce the probability of ice nucleation directly on the surface. Prior to the treatment with DCDMS the glass slide was thoroughly cleaned in "piranha" solution (3:1 mixture by volume of sulfuric acid and hydrogen peroxide), rinsed in high-purity water (distilled water further purified with a Millipore system) and methanol (HPLC grade). Any remaining contaminant particles removed with a dry ice cleaning system (Sno Gun-II ${ }^{\mathrm{TM}}$, Va-Tran Systems). The treatment with DCDMS involved placing the slides in an airtight chamber together with 2-3 droplets of DCDMS solution (Fluka, 5\% DCMS in heptane). The slides were not in direct contact with the DCDMS, rather the DCDMS coated the glass slides via vapor deposition.

[12] All samples were prepared and the flow cell constructed within a filtered air laminar flow hood. This greatly reduced the possibility of sample contamination by ambient atmospheric and laboratory particles. All mineral dust particles with the exception of calcite were deposited on a hydrophobic glass slide using the following technique: the dry dust particulates were placed in a glass vessel immersed in an ultrasonic bath. A flow of ultra-high-purity $\mathrm{N}_{2}$ was passed through the glass vessel, and vibrations from the ultrasonic bath caused the dust particles to be suspended in the flow of $\mathrm{N}_{2}$. This flow was then directed at the hydrophobic glass slide, and the dust particles were deposited on the slide by impaction. Calcite particles were not readily suspended by the vibrations from the ultrasonic bath, so these were deposited on the hydrophobic slide simply by sprinkling them directly on the slide using a small spatula. In all cases, dust particles deposited on the slide were less than $50 \mu \mathrm{m}$ in diameter. The optical resolution limit of the microscope was $\sim 1 \mu \mathrm{m}$. A typical sample held between 100 to 1000 individual particles, the majority of which were between 1 and $20 \mu \mathrm{m}$ in diameter. The average sizes of the particles used in our experiments were $7.7 \mu \mathrm{m}$ for kaolinite, $9.0 \mu \mathrm{m}$ for muscovite, $8.1 \mu \mathrm{m}$ for montmorillonite, $10.0 \mu \mathrm{m}$ for quartz and $14.2 \mu \mathrm{m}$ for calcite based on the optical microscope images.

[13] During the ice nucleation experiments, a flow of humidified He gas was introduced to one side of the cell and exited on the other where its frost point was measured with a frost point hygrometer (General Eastern). From the frost point measurements, the water vapor pressure $\left(p_{\mathrm{H} 2 \mathrm{O}}\right)$ was calculated using the parameterization of Murphy and Koop [2005]. A flow of humidified gas was generated by passing a flow of ultra-high-purity $\mathrm{He}$ gas (99.999 \%) over a reservoir of ultra-pure water (distilled water further purified using a Millipore system). The desired $p_{\mathrm{H} 2 \mathrm{O}}$ was adjusted by altering the temperature of the water reservoir and diluting the humidified flow with a second flow of dry He. A continuous flow of between 1900 to $2100 \mathrm{~cm}^{3} \mathrm{~min}^{-1}$ (at $273.15 \mathrm{~K}$ and $1 \mathrm{~atm}$ ) was maintained throughout the course of the ice nucleation experiments. For purification, the He gas used in these experiments was first passed through a trap containing molecular sieve (1/16" pellets, Type T4A) at $77 \mathrm{~K}$ and then through a $0.02 \mu \mathrm{m}$ filter (Anodisc 25).

[14] In our experimental apparatus, a Pt-100 resistance temperature detector (RTD) was located just beneath the slide containing the mineral dust particles. The RTD was calibrated against the dew point or ice frost point within the cell, similar to methods used by other researchers [Middlebrook et al., 1993; Parsons et al., 2004b; Dymarska et al., 2006]. Calibration involved observing the change in size of ice crystals on the slide as the temperature was ramped up and down. The temperature at which the size of the ice crystals remained constant was determined from these measurements; at that point the ice crystals were in equilibrium with the water vapor inside the cell, whose frost point was precisely known from the hygrometer measurements. Hence it was possible to determine the offset temperature between the temperature reported by the RTD and the temperature of the ice crystals formed on the hydrophobic glass slide in the cell, and use this offset to correct experimentally measured temperatures obtained with the RTD.

[15] The $\mathrm{RH}_{\mathrm{i}}$ within the cell was then calculated using equation (1):

$$
\mathrm{RH}_{\mathrm{i}}=p_{\mathrm{H} 2 \mathrm{O}} / p_{\text {ice }}\left(T_{\text {cell }}\right) * 100
$$

Where $p_{\text {ice }}\left(T_{\text {cell }}\right)$ is the saturation vapor pressure of ice at the temperature of the cell, calculated using the parameterization of Murphy and Koop [2005].

[16] In each ice nucleation experiment, the $\mathrm{RH}_{\mathrm{i}}$ was ramped from below $100 \%$ to water saturation by decreasing 


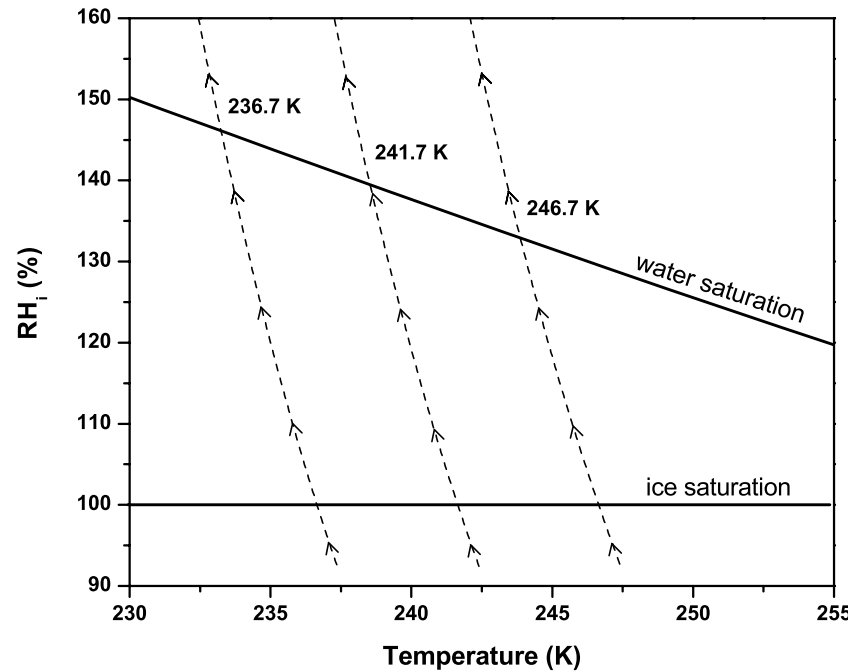

Figure 2. Typical experimental trajectories of $\mathrm{RH}_{\mathrm{i}}$, where temperature was reduced at a rate of $0.1 \mathrm{~K} \mathrm{~min}^{-1}$, while the water partial pressure was constant. The trajectories were calculated using the saturation vapor pressures of water and ice from the parameterizations of Murphy and Koop [2005].

the temperature of the cell at approximately $0.1 \mathrm{~K} \mathrm{~min}^{-1}$ (corresponding to a change in $\mathrm{RH}_{\mathrm{i}}$ of approximately $1 \%$ $\min ^{-1}$ ) while maintaining a constant $p_{\mathrm{H} 2 \mathrm{O}}$ inside the cell. Typical experimental $\mathrm{RH}_{\mathrm{i}}$ trajectories are illustrated in Figure 2 for three different initial temperatures of $246.7 \mathrm{~K}$, $241.7 \mathrm{~K}$, and $236.7 \mathrm{~K}$. Images of the dust particles were recorded digitally every 20 seconds or $\sim 0.033 \mathrm{~K}$, while simultaneously recording $p_{\mathrm{H} 2 \mathrm{O}}$ and the cell temperature. From these images, the $\mathrm{RH}_{\mathrm{i}}$ and temperature at which ice crystals first formed was determined (i.e., the onset conditions of ice nucleation). Shown in Figure 3 are images of the kaolinite particles recorded in a typical freezing experiment before and after ice nucleation, respectively. The formation of ice crystals is clearly discernable.

\section{Results and Discussion}

\subsection{Measurements of Onset Conditions of Ice Nucleation}

[17] As mentioned above, the onset conditions were determined for muscovite, kaolinite, montmorillonite,

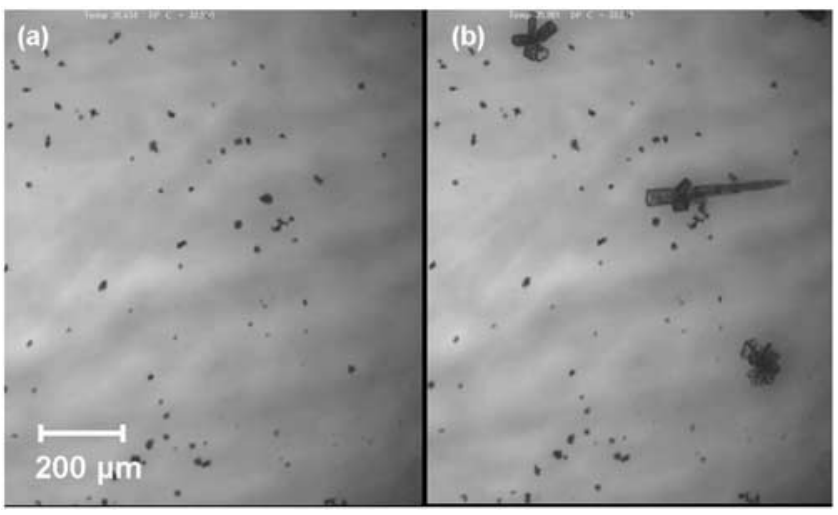

Figure 3. Optical microscope images of kaolinite particles (a) before and (b) after ice nucleation. quartz and calcite. The total surface area of mineral dust exposed in any particular experiment ranged from $5 \times 10^{-5}$ to $5 \times 10^{-3} \mathrm{~cm}^{2}$, based on the geometric surface area of the particles. Shown in Figure 4 are the onset conditions for all five minerals at each of the three temperatures studied. The error bars represent $95 \%$ confidence intervals based on at least six measurements per data point. For kaolinite, muscovite and montmorillonite ice nucleation occurred below liquid water saturation and there was no indication of liquid water condensing prior to ice nucleation as expected. This is also the case for quartz and calcite at the two lowest temperatures. For these experiments the data correspond to deposition freezing, which occurs when vapor absorbs onto a solid surface and is transformed into ice [Valie, 1985]. For quartz and calcite at the warmest temperature studied the data overlap with liquid water saturation. For approximately half of the quartz and calcite experiments at the warmest temperature we observed only ice nucleation with no indication of liquid water condensation prior to ice nucleation. For the other half of the quartz and calcite experiments at the warmest temperature we first observed the condensation of liquid water. In this case it appears that condensation freezing may be important. Condensation freezing refers to the sequence of events whereby liquid water first condenses followed by freezing of the liquid [Valie, 1985].

[18] On the basis of Figure 4, kaolinite and muscovite are effective ice nuclei at all temperatures studied, with onset $\mathrm{RH}_{\mathrm{i}}$ values below $112 \%$. Quartz and calcite were poor ice nuclei at all temperatures studied, requiring relative humidities close to water saturation before ice nucleation occurred. Montmorillonite was an effective ice nucleus at the two lowest temperatures studied (236.0 and $240.8 \mathrm{~K}$ ), but a relatively poor ice nucleus at the highest temperature studied (244.6 K). Overall, the data show significant differences in the ice nucleating abilities of the five minerals studied over this temperature range.

[19] The reason why some minerals are better ice nuclei than others is still relatively poorly understand. However, previous research suggests that it is likely a combination of the strengths of the chemical bonds at the mineral surface, the crystallographic match between the substrate and ice

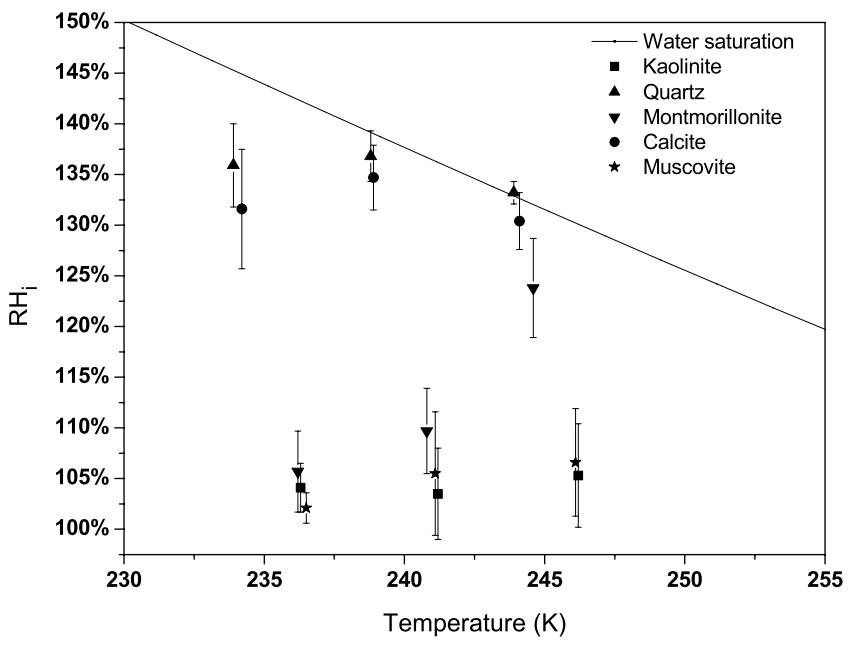

Figure 4. Onset conditions for all minerals studied. 
Table 3. Summary of Experimental Conditions for Previously Published Results

\begin{tabular}{lccc}
\hline \multicolumn{1}{c}{ Study } & $\begin{array}{c}\text { Size } \\
\text { Range }(\mu \mathrm{m})\end{array}$ & $\begin{array}{c}\text { Number } \\
\text { of Particles }\end{array}$ & $\begin{array}{c}\text { Surface Area } \\
\text { Range }\left(\mathrm{cm}^{2}\right)\end{array}$ \\
\hline Current study & $1-50$ & $10^{2}-10^{3}$ & $3 \times 10^{-6}-1 \times 10^{-2}$ \\
Roberts and Hallett [1968] & $0.5-3$ & $10^{1}-10^{4}$ & $8 \times 10^{-8}-3 \times 10^{-3}$ \\
Bailey and Hallett [2002] & $5-10$ & Not determined & Not determined \\
Kanji and Abbatt [2006] & $0.5-5$ & $4.6 \times 10^{2}-3.2 \times 10^{4}$ & $9 \times 10^{-5}-3 \times 10^{-2}$ \\
Dymarska et al. $[2006]$ & $1-20$ & $2 \times 10^{2}-8 \times 10^{2}$ & $6 \times 10^{-6}-1 \times 10^{-2}$ \\
Salam et al. $[2006]$ & $<0.5-5$ & Not determined & at determined $^{\mathrm{a}}$ \\
Zimmerman et al. $[2007]$ & $1-10$ & Not determined $^{\mathrm{b}}$ & Not determined $^{\mathrm{b}}$ \\
\hline
\end{tabular}

${ }^{a}$ These authors used a continuous flow diffusion chamber. Typical total aerosol number concentrations were $<15$ particles $\mathrm{cm}^{-3}$

${ }^{\mathrm{b}}$ Zimmerman et al. [2007] spread particles on a silicon plate $(5 \times 5 \mathrm{~mm})$, and the particle density was $100-150$ particles/ $\mathrm{mm}^{2}$. However, the exact fraction of particles activated could not be determined precisely because only a small part of the total silicon plate was imaged.

embryo, and the presence of active sites on the mineral surface, which can promote ice nucleation [Pruppacher and Klett, 1997]. For example, it has been speculated that the relatively good ice nucleation ability of kaolinite may be due to the pseudo-hexagonal arrangement of the hydroxyl $(-\mathrm{OH})$ groups at the kaolinite surface [Pruppacher and Klett, 1997]. Our laboratory results provide further data that can be used to test these various theories.

[20] In our experiments, the mineral particles are suspended on a hydrophobic glass substrate. Before we discuss our results further, we first address the possible effect of the hydrophobic glass substrate on the ice nucleation results.

[21] First, in blank experiments (when no mineral dust was used) ice nucleation did not occur below liquid water saturation, (see Figure 4a in the study of Dymarska et al. [2006]). Second, from direct observations of the optical images we confirmed that ice nucleation always occurred on a mineral particle, rather than a bare spot on the hydrophobic glass substrate. Third, to further ensure that the hydrophobic glass support was not influencing our results, we did some tests with other types of supports. Tests were carried out with bare glass slides that were not coated with the hydrophobic monolayer. In this case the glass slides were just cleaned as described above, resulting in a hydrophilic substrate. Also, tests were carried out using thin Teflon sheets as the bottom surface of the flow cell. In the test experiments we measured the onset conditions for ice nucleation on kaolinite particles using the different supports (bare glass, hydrophobic glass, and Teflon). Within the uncertainty of our measurements, the results were independent of the type of support used. This gives further confidence that the hydrophobic glass support is not influencing our results.

[22] Below we compare our onset conditions with results published in the literature. The comparison below focuses mainly on results from six different studies: those of Roberts and Hallett [1968], Bailey and Hallett [2002], Dymarska et al. [2006], Kanji and Abbatt [2006], Salam et al. [2006] and Zimmerman et al. [2007]. Some of the experimental conditions from these measurements are listed in Table 3 for reference.

\subsection{Comparison of Measured Onset Conditions for Kaolinite With Literature Data}

[23] In Figure 5, we compare our kaolinite results with previous measurements. At our temperature range, there have been three previous studies: those of Dymarska et al. [2006], Bailey and Hallett [2002], and Salam et al. [2006]. The data from Dymarska et al. [2006] are in agreement with our measurements, which is not surprising since the same instrument and experimental protocol were employed. The onset conditions for Salam et al. [2006] are also in agreement with our current studies at 233 to $246 \mathrm{~K}$. These authors observed that $0.5 \%$ of the kaolinite particles activated as ice nuclei even at the lowest supersaturations with respect to ice (close to $100 \%$ ). The fraction of particles activated remained almost constant in these studies until above $120-130 \% \mathrm{RH}_{\mathrm{i}}$ at which point the fraction activated increased sharply. The results from Bailey and Hallett [2002] differ from our results by approximately $10-15 \%$ $\mathrm{RH}_{\mathrm{i}}$. These differences may be due to variation in mineral surface area available in the different experiments, variation in particle diameters, or variability due to different experimental techniques or different observation times in the experiments. Also, differences in the source of the kaolinite particles may result in some variability in the interaction of the particles with water. Hoffer [1961] and Schuttlefield et al. [2007] reported that water uptake by kaolinite and montmorillonite varied significantly with the location of the mineral source. These points should be investigated in more detail in future experiments.

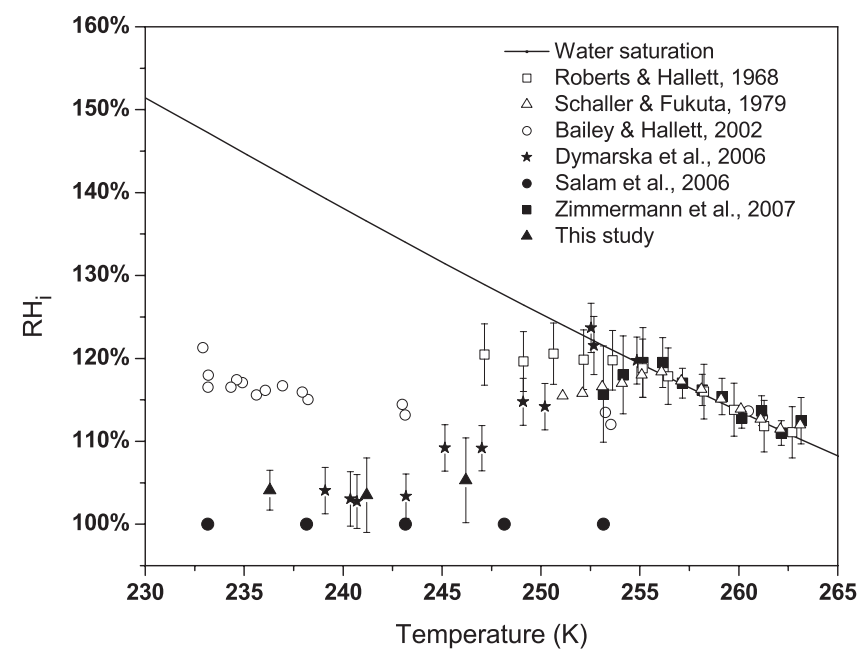

Figure 5. Summary of ice nucleation results for kaolinite. 


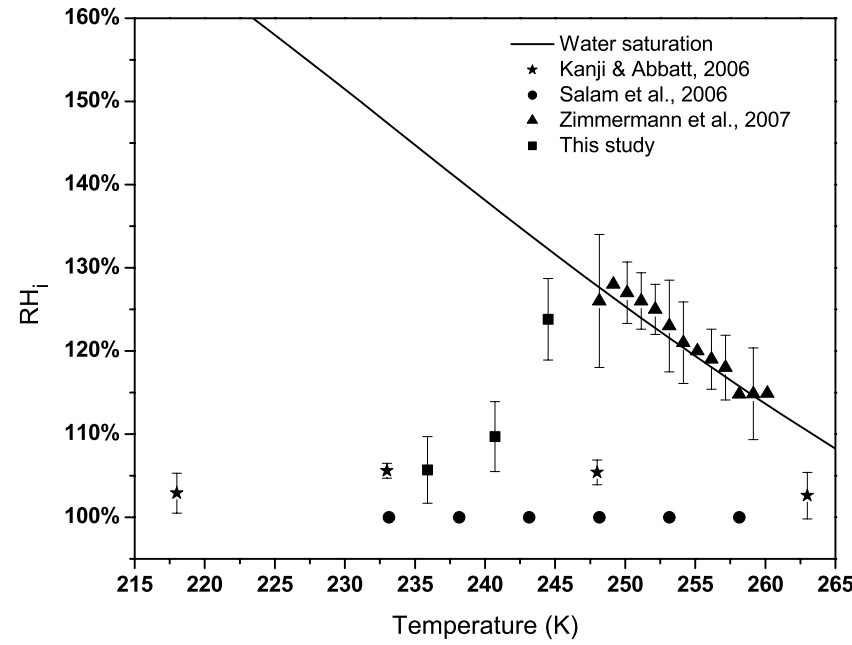

Figure 6. Summary of ice nucleation results for montmorillonite.

[24] If we consider all the data shown in Figure 5, the following conclusions seem appropriate. At temperatures above $255 \mathrm{~K}$, ice nucleation does not occur until liquid water saturation is reached. At temperatures below $250 \mathrm{~K}$, all data suggest that kaolinite is an effective ice nucleus (i.e., $\mathrm{RH}_{\mathrm{i}}$ values less than water saturation are required for ice nucleation). Quantitatively, however, there are relatively large differences between the different experiments at temperatures below $250 \mathrm{~K}$ as mentioned above.

\subsection{Comparison of Measured Onset Conditions for Montmorillonite With Literature Data}

[25] In Figure 6 we compare our ice nucleation data for montmorillonite with previous data from Kanji and Abbatt [2006], Salam et al. [2006] and Zimmerman et al. [2007]. Our results are consistent with the more recent study by Zimmerman et al. [2007] if we extrapolate our results to warmer temperatures, but appear to be inconsistent with the results from Kanji and Abbatt [2006]. At the warmer temperatures our results also appear to be inconsistent with the results from Salam et al. [2006]. These authors found that $1.2 \%$ of montmorillonite particles were active ice nuclei even at very small supersaturations with respect to ice $\left(\mathrm{RH}_{\mathrm{i}} \approx\right.$ $100 \%$ ) over the temperature range of $258 \mathrm{~K}$ and $233 \mathrm{~K}$. The fraction of particles activated remained almost constant until above approximately $107-115 \% \mathrm{RHi}$, at which point the fraction activated, increased sharply.

[26] Not shown in Figure 6 are the results from Roberts and Hallett [1968]. Roberts and Hallett [1968] observed ice nucleation at $248 \mathrm{~K}$ and at liquid water saturation when using approximately $10^{4}$ particles. This result is consistent with our observations.

[27] Overall, there appear to be large differences between some of the montmorillonite studies. Some possible reasons for these differences are discussed above. Kanji and Abbatt [2006] also presented other reasons why their results may differ from other measurements. First, they suggested a time dependence may be causing the observed differences, with longer exposure times leading to lower $\mathrm{RH}_{\mathrm{i}}$ values required for activation. Second, they suggested that some of the differences may be due to different preparation techniques.
Kanji and Abbatt [2006] prepared their particles by nebulizing an aqueous suspension of the mineral dust. In contrast, all other studies mentioned above for montmorillonite used dry dispersion. Future studies that investigate the effect of these different parameters are needed for a complete understanding of ice nucleation on mineral particles.

\subsection{Comparison of Measured Onset Conditions for Muscovite, Quartz, and Calcite With Literature Data}

[28] To our knowledge, these are the first measurements of the onset conditions (both $\mathrm{RH}_{\mathrm{i}}$ and temperature) for ice nucleation on muscovite. Mason and Maybank [1958] reported that muscovite was inactive as an ice nucleus at temperatures above $255 \mathrm{~K}$, which does not contradict our results.

[29] For quartz, there are no previous reports of the onset conditions for ice nucleation. Mason and Maybank [1958] reported that this mineral was inactive as an ice nucleus above $248 \mathrm{~K}$, which is consistent with our data.

[30] For calcite, Roberts and Hallett [1968] reported one temperature $(255 \mathrm{~K})$ and $\mathrm{RH}_{\mathrm{i}}(120 \%)$ at which one particle in $10^{4}$ nucleated ice. These conditions correspond to liquid water saturation. At $244 \mathrm{~K}$, the warmest temperature we investigated, we also observed that relative humidities close to liquid water saturation were needed for ice nucleation. We conclude that the limited results from Roberts and Hallett [1968] do not contradict our measurements.

\subsection{Nucleation Rates, $\boldsymbol{J}_{\text {het }}$}

[31] Above we reported onset conditions $\left(\mathrm{RH}_{\mathrm{i}}\right.$ and temperature), which may depend on several experimental parameters, such as observation time and surface area available for nucleation. A more useful parameter for describing ice nucleation is the heterogeneous nucleation rate, $J_{\text {het }}$, which allows for a more direct comparison between laboratory studies and for extrapolation to the atmosphere. $J_{\text {het }}$ is defined as the number of nucleation events per unit surface area of solid material per unit time. Note that $J_{\text {het }}$ is referred to as both a rate [Pruppacher and Klett, 1997; Martin, 2000; Hung et al., 2003; Parsons et al., 2004a, 2004b; Archuleta et al., 2005; Pant et al., 2006] and a rate coefficient [Dymarska et al., 2006; Marcolli et al., 2007] in the literature. The heterogeneous nucleation rate is related to the onset data through equation (2):

$$
J_{\text {het }}=\omega / \mathrm{A}_{\mathrm{s}} \mathrm{t}
$$

where $\omega$ is the number of ice crystals nucleated, $A_{\mathrm{s}}$ is the total mineral dust surface area available for heterogeneous nucleation, and $t$ is the observation time. At the onset of ice nucleation, $\omega$ was equal to one.

[32] Table 4 lists the nucleation rates determined in our experiments. The uncertainty in $J_{\text {het }}$ was determined by considering the uncertainties in $\mathrm{A}_{\mathrm{s}}$ and $\mathrm{t}$. We used $10 \mathrm{~s}$ for the observation time with an upper limit of $20 \mathrm{~s}$ (the time between image captures) and a lower limit of $1 \mathrm{~s}$. Note, however, that nucleation may have happened at a shorter time than 1 second. If this is the case the calculated nucleation rates will be lower limits to the true nucleation rates. For the surface area available for nucleation we used the geometric surface area of the particles determined directly from the optical microscope images using digital 
Table 4. $J$ Values and Contact Angles for all Five Minerals Studied

\begin{tabular}{|c|c|c|c|c|c|c|c|c|}
\hline Mineral & $\begin{array}{c}\text { Onset } \\
\text { Temperature }(\mathrm{K})\end{array}$ & $\mathrm{RH}_{\text {ice }}$ & $\begin{array}{c}J_{\text {het }} \\
\left(\mathrm{cm}^{-2} \mathrm{~s}^{-1}\right)\end{array}$ & $\begin{array}{l}J_{\text {het, upper }} \\
\left(\mathrm{cm}^{-2} \mathrm{~s}^{-1}\right)\end{array}$ & $\begin{array}{l}J_{\text {het, lower }} \\
\left(\mathrm{cm}^{-2} \mathrm{~s}^{-1}\right)\end{array}$ & $\theta_{\text {lower }}$ & $\theta$ & $\theta_{\text {upper }}$ \\
\hline Kaolinite & 246.1 & $105 \pm 5$ & 420 & 4200 & 4.2 & 5.2 & 9.7 & 13.9 \\
\hline Kaolinite & 241.1 & $104 \pm 5$ & 200 & 2000 & 2.0 & 2.4 & 7.8 & 12.4 \\
\hline Kaolinite & 236.4 & $104 \pm 2$ & 280 & 2800 & 2.8 & 3.4 & 9.2 & 13.5 \\
\hline Muscovite & 246.2 & $107 \pm 5$ & 940 & 9400 & 9.4 & 7.1 & 10.7 & 14.7 \\
\hline Muscovite & 241.3 & $106 \pm 6$ & 2200 & 22,000 & 22 & 5.5 & 9.5 & 14.3 \\
\hline Muscovite & 237.0 & $102 \pm 2$ & 490 & 4900 & 4.9 & 0.7 & 6.2 & 11.2 \\
\hline Montmorillonite & 244.6 & $124 \pm 5$ & 460 & 4600 & 4.6 & 19.6 & 22.3 & 25.3 \\
\hline Montmorillonite & 240.8 & $110 \pm 4$ & 870 & 8700 & 8.7 & 10.9 & 14.3 & 17.6 \\
\hline Montmorillonite & 236.0 & $106 \pm 4$ & 930 & 9300 & 9.3 & 7.7 & 12.0 & 15.6 \\
\hline Quartz & 243.9 & $133 \pm 1$ & 360 & 3600 & 3.6 & - & - & - \\
\hline Quartz & 238.7 & $137 \pm 3$ & 340 & 3400 & 3.4 & 24.5 & 27.1 & 30.1 \\
\hline Quartz & 234.0 & $136 \pm 4$ & 480 & 4800 & 4.8 & 23.7 & 26.3 & 29.3 \\
\hline Calcite & 244.1 & $130 \pm 3$ & 620 & 6200 & 6.2 & - & - & - \\
\hline Calcite & 238.9 & $135 \pm 3$ & 250 & 2500 & 2.5 & 23.8 & 26.4 & 29.4 \\
\hline Calcite & 234.2 & $132 \pm 6$ & 130 & 1300 & 1.3 & 22.2 & 24.9 & 27.9 \\
\hline
\end{tabular}

image software (Northern Eclipse). For an upper limit to the surface area available for nucleation we multiplied the geometric surface area of the particles by a factor of 50, based on scanning electron microscope (SEM) measurements where we more accurately determined the specific surface area of a limited number of particles. The data shown in Table 4 suggests that our experiments are typically sensitive to values of $J_{\text {het }}$ ranging from 1 to $22000 \mathrm{~cm}^{-2} \mathrm{~s}^{-1}$.

3.6. Classical Nucleation Theory Parameters From $\boldsymbol{J}_{\text {het }}$

[33] The applicability of standard classical nucleation theory to heterogeneous nucleation on minerals remains to be determined. In fact, some measurements show that for precise predictions, active site theory is required. See for example the studies of Hung et al. [2003], Archuleta et al. [2005], and Marcolli et al. [2007]. Nevertheless, classical nucleation theory has been used in the past to describe heterogeneous nucleation in atmospheric cloud models [Kärcher, 1996, 1998; Jensen and Toon, 1997; Jensen et al., 1998; Kärcher et al., 1998; Demott, 2002; Morrison et $a l ., 2005]$. Also classical nucleation theory is a relatively convenient and simple way to parameterize laboratory data. Hence classical nucleation theory is a reasonable starting point for analyzing our experimental data. Below we analyze the nucleation rates using classical nucleation theory. From this analysis, we determined the contact angle between an ice nucleus and the mineral surface.

[34] For this analysis we only consider the case of deposition freezing. As a result, we do not consider any nucleation data where the onset conditions overlap the liquid water saturation line, since in this case nucleation may have occurred by either deposition or condensation freezing, as discussed above.

[35] According to standard classical nucleation theory, the rate of heterogeneous nucleation $\left(J_{\text {het }}\right)$ by deposition freezing is defined as: [Pruppacher and Klett, 1997]

$$
J_{\text {het }}=\mathrm{A} \cdot \exp \frac{-\Delta \mathrm{F}_{\mathrm{g}, \text { het }}}{\mathrm{kT}}
$$

where $\mathrm{A}$ is the pre-exponential factor in units of $\mathrm{cm}^{-2} \mathrm{~s}^{-1}$, $\Delta F_{g, h e t}$ is the free energy of formation of the critical embryo in joules $(\mathrm{J}), \mathrm{k}$ is the Boltzmann constant in $\mathrm{J} \mathrm{K}^{-1}$, and $\mathrm{T}$ is the temperature in K. Assuming that an ice embryo on a curved solid substrate can be described as a spherical cap model, the free energy of formation of the critical embryo is given by [Pruppacher and Klett, 1997]:

$$
\Delta \mathrm{F}_{\mathrm{g}, \text { het }}=\frac{16 \pi \mathrm{M}_{\mathrm{w}}^{2} \sigma_{\mathrm{i} / \mathrm{v}}^{3}}{3\left[\mathrm{RT} \rho \operatorname{InS} \mathrm{S}_{\mathrm{i}}\right]} \cdot \mathrm{f}(\mathrm{m}, \mathrm{x})
$$

where $\mathrm{M}_{\mathrm{w}}$ is the molecular weight of water in $\mathrm{g} \mathrm{mol}^{-1}, \sigma_{\mathrm{i} / \mathrm{v}}$ is the surface tension at the ice-vapor interface in $\mathrm{mJ} \mathrm{m}^{-2}, \mathrm{R}$ is the universal gas constant in $\mathrm{J} \mathrm{mol}^{-1} \mathrm{~K}^{-1}, \rho$ is the density of ice in $\mathrm{g} \mathrm{cm}^{-3}, \mathrm{~S}_{\mathrm{i}}$ is the supersaturation ratio with respect to an ice surface, $\mathrm{f}(\mathrm{m}, \mathrm{x})$ is the geometric factor, $\mathrm{m}$ is the compatibility parameter for ice on a solid substrate, and $\mathrm{x}$ is the ratio of the radius of the substrate to the radius of spherical ice germ. The compatibility parameter, $m$, is equal to $\cos \theta$, where $\theta$ is the contact angle between an ice nucleus and the mineral surface.

[36] Assuming the radius of the substrate to be much larger than the radius of the ice germ (a good approximation under our experimental conditions $), f(m, x)$ is defined as follows:

$$
f(m, x)=\frac{m^{3}-3 m+2}{4}
$$

To calculate $\theta$, we first calculated the free energy of formation of the critical nucleus using equation (3), our experimentally determined $J_{\text {het }}$ values, and assuming a preexponential term (A) equal to $10^{25} \mathrm{~cm}^{-2} \mathrm{sec}^{-1}$ [Fletcher, 1958, 1959; Pruppacher and Klett, 1997]. Then, we calculated the contact angle $(\theta)$ using equations (4) and (5), assuming the density of ice $(\rho)$ is $0.92 \mathrm{~g} \mathrm{~cm}^{-3}[C R C$, 2001-2002], $\mathrm{M}_{\mathrm{w}}$ is $18.015 \mathrm{~g} \mathrm{~mol}^{-1}$, and $\sigma_{\mathrm{i} / \mathrm{v}}$ equals $106 \pm$ $5 \mathrm{~mJ} \mathrm{~m}^{-2}$ [Pruppacher and Klett, 1997]. For $\sigma_{\mathrm{i} / \mathrm{v}}$, we are using the surface tension appropriate for hexagonal ice. Recent work has shown that cubic ice is the first phase to nucleate when homogeneous nucleation dominates [Murray et al., 2005; Murray and Bertram, 2006], but further research is needed to determine if this also the case for heterogeneous nucleation. 


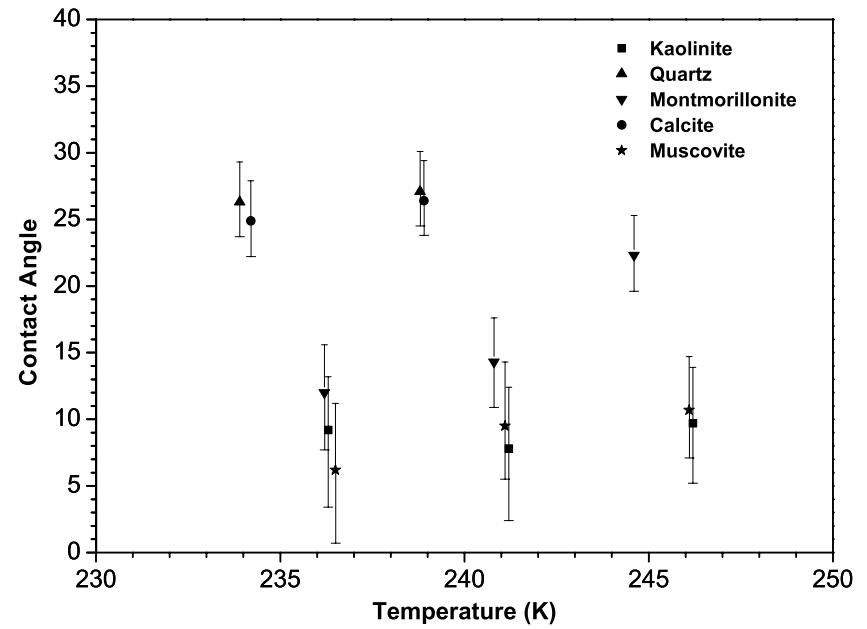

Figure 7. Contact angle as a function of temperature for each mineral studied.

[37] In Table 4, the contact angles calculated using the procedure discussed above are listed. The contact angle values are also illustrated in Figure 7. The data show that for efficient ice nuclei such as muscovite and kaolinite, the contact angles are small (below $18^{\circ}$ ). For poor ice nuclei such as quartz and calcite, the contact angles are larger (above $20^{\circ}$ ). These values may be useful for future modeling studies of ice nucleation in the atmosphere and for comparing results between different laboratories.

\section{Summary and Conclusions}

[38] An optical microscope coupled to a flow cell was use to characterize the ice nucleation ability of muscovite, kaolinite, montmorillonite, quartz and calcite over the temperature range of 233 to $247 \mathrm{~K}$. Onset conditions for ice nucleation, nucleation rates and contact angles were determined.

[39] Onset measurements indicate that muscovite and kaolinite are very good ice nuclei with onset $\mathrm{RH}_{\mathrm{i}}$ values of less than approximately $110 \%$, well below water saturation. This can be explained by a better crystallographic match between the pseudo-hexagonal arrangement of the hydroxyl $(-\mathrm{OH})$ groups at the kaolinite surface and the hexagonal ice structure which allows a better hetero-epitaxial growth of the ice structure though a H-bond framework [Pruppacher and Klett, 1997]. Onset measurements indicate that quartz and calcite are the poorest ice nuclei. For the temperature range studied, the $\mathrm{RH}_{\mathrm{i}}$ values needed to induce ice nucleation on quartz and calcite are approximately 20 to $40 \%$ higher than those needed for kaolinite and muscovite. In contrast, montmorillonite was an effective ice nucleus at the two lowest temperatures studied (236.0 and $240.8 \mathrm{~K}$ ), but a relatively poor ice nucleus at the highest temperature studied $(244.6 \mathrm{~K})$, based on the onset data. Overall, the data show significant differences in the ice nucleating abilities of the five minerals studied over this temperature range.

[40] The measured onset conditions for the mineral dusts were compared with previously published data. In several cases, there was a lack of quantitative agreement among published work. This can be explained by several factors including the mineral source, the particle sizes, the surface area available for nucleation, observation and equilibrium times. Future studies that investigate the effect of these different parameters are needed for a complete understanding of ice nucleation on mineral particles.

[41] The heterogeneous nucleation rates $\left(J_{\text {het }}\right)$ and contact angles $(\theta)$ were determined according to classical nucleation theory for all five minerals studied. The contact angles measured for kaolinite and muscovite ranged from 6 to $12^{\circ}$; whereas for quartz and calcite the contact angles ranged from 25 to $27^{\circ}$. The reported $J_{\text {het }}$ and $\theta$ values may allow for a more direct comparison between laboratory studies and can be used when modeling ice cloud formation in the atmosphere. Future studies should investigate the dependence of onset conditions and nucleation rates on particle size and the surface area available for nucleation to establish more accurate predictions of ice nucleation in the atmosphere.

[42] Acknowledgments. The authors would like to thank B. J. Murray, D. A. Knopf, and D. L. Macalady for their many helpful discussions. This research was supported by the Canadian Foundation for Climate and Atmospheric Science (CFCAS), the Natural Sciences and Engineering Research Council of Canada (NSERC), and the Canada Research Chair Program.

\section{References}

Anthony, J. W., R. A. Bideaux, K. W. Bladh, and M. C. Nichols (1995), Handbook of Mineralogy, Mineral Data, Tucson, Ariz.

Archuleta, C. M., P. J. Demott, and S. M. Kreidenweis (2005), Ice nucleation by surrogates for atmospheric mineral dust and mineral dust/sulfate particles at cirrus temperatures, Atmos. Chem. Phys., 5, 2617-2634.

Bailey, M., and J. Hallett (2002), Nucleation effects on the habit of vapour grown ice crystals from -18 to $-42{ }^{\circ} \mathrm{C}$, Q. J. R. Meteorol. Soc., 128, $1461-1483$.

Cantrell, W., and A. J. Heymsfield (2005), Production of ice in tropospheric clouds-A review, Bull. Am. Meteorol. Soc., 86(6), 795-807.

Chen, Y. L., S. M. Kreidenweis, L. M. McInnes, D. C. Rogers, and P. J. DeMott (1998), Single particle analyses of ice nucleating aerosols in the upper troposphere and lower stratosphere, Geophys. Res. Lett., 25(9), $1391-1394$.

Cziczo, D. J., D. M. Murphy, P. K. Hudson, and D. S. Thomson (2004), Single particle measurements of the chemical composition of cirrus ice residue during CRYSTAL-FACE, J. Geophys. Res., 109(D4), D04201, doi:10.1029/2003JD004032.

DeMott, P. J. (2002), Laboratory studies of cirrus cloud processes, in Cirrus, edited by D. K. Lynch, pp. 102-136, Oxford Univ. Press, New York. DeMott, P. J., K. Sassen, M. R. Poellot, D. Baumgardner, D. C. Rogers, S. D. Brooks, A. J. Prenni, and S. M. Kreidenweis (2003a), African dust aerosols as atmospheric ice nuclei, Geophys. Res. Lett., 30(14), 1732, doi:10.1029/2003GL017410.

Demott, P. J., D. J. Cziczo, A. J. Prenni, D. M. Murphy, S. M. Kreidenweis, D. S. Thomson, R. Borys, and D. C. Rogers (2003b), Measurements of the concentration and composition of nuclei for cirrus formation, Proc. Natl. Acad. Sci. U.S.A., 100(25), 14,655-14,660.

Dymarska, M., B. J. Murray, L. M. Sun, M. L. Eastwood, D. A. Knopf, and A. K. Bertram (2006), Deposition ice nucleation on soot at temperatures relevant for the lower troposphere, J. Geophys. Res., 111(D4), D04204, doi:10.1029/2005JD006627.

Field, P. R., O. Möhler, P. Connolly, M. Krämer, R. Cotton, A. J. Heymsfield, H. Saathoff, and M. Schnaiter (2006), Some ice nucleation characteristics of Asian and Saharan desert dust, Atmos. Chem. Phys., 6, 2991-3006.

Fletcher, N. H. (1958), Size effect in heterogeneous nucleation, J. Chem. Phys., 29(3), 572-576.

Fletcher, N. H. (1959), On ice-crystal production by aerosol particles, J. Meteorol., 16, 173-180.

Fletcher, N. H. (1962), Physics of Rainclouds, Cambridge Univ. Press, London, U.K.

Girard, E., and J. A. Curry (2001), Simulation of low-level tropospheric clouds during FIRE experiment in May 1998, J. Geophys. Res., 106(D14), 15,139-15,154.

Girard, E., J.-P. Blanchet, and Y. Dubois (2005), Effects of sulphuric acid aerosols on wintertime low-level atmospheric ice crystals, humidity, and temperature at Alert, Nunavut, Atmos. Res., 73, 131-148. 
Glaccum, R. A., and J. M. Prospero (1980), Saharan aerosols over the tropical North Atlantic-Mineralogy, Mar. Geol., 37, 295-321.

Haag, W., and B. Kärcher (2004), The impact of aerosols and gravity waves on cirrus clouds at midlatitudes, J. Geophys. Res., 109, D12202, doi:10.1029/2004JD004579.

Hanisch, F., and J. N. Crowley (2001), The heterogeneous reactivity of gaseous nitric acid on authentic mineral dust samples, and on individual mineral and clay mineral components, Phys. Chem. Chem. Phys., 3 , 2474-2482.

Heintzenberg, J., K. Okada, and J. Ström (1996), On the composition of non-volatile material in upper tropospheric aerosols and cirrus crystals, Atmos. Res., 41, 81-88.

Hoffer, T. E. (1961), A laboratory investigation of droplet freezing, J. Meteorol., 18, 766-778.

Hung, H. M., A. Malinowski, and S. T. Martin (2003), Kinetics of heterogeneous ice nucleation on the surfaces of mineral dust cores inserted into aqueous ammonium sulfate particles, J. Phys. Chem. A, 107(9), 12961306.

Jensen, E. J., and O. B. Toon (1997), The potential impact of soot particles from aircraft exhaust on cirrus clouds, Geophys. Res. Lett., 24(3), 249252.

Jensen, E. J., O. B. Toon, R. F. Pueschel, J. Goodman, G. W. Sachse, B. E. Anderson, K. R. Chan, D. Baumgardner, and R. C. Miake-Lye (1998), Ice crystal nucleation and growth in contrails forming at low ambient temperatures, Geophys. Res. Lett., 25(9), 1371-1374.

Kanji, Z. A., and J. P. D. Abbatt (2006), Laboratory studies of ice formation via deposition mode nucleation onto mineral dust and n-hexane soot samples, J. Geophys. Res., 111(D16), D16204, doi:10.1029/2005JD006766.

Kärcher, B. (1996), Aircraft-generated aerosols and visible contrails, Geophys. Res. Lett., 23(15), 1933-1936.

Kärcher, B. (1998), Physicochemistry of aircraft-generated liquid aerosols, soot, and ice particles-1: Model description, J. Geophys. Res. 103(D14), 17,111-17,128.

Kärcher, B. (2004), Cirrus clouds in the tropical tropopause layer: Role of heterogeneous ice nuclei, Geophys. Res. Lett., 31, L12101, doi:10.1029/ 2004GL019774.

Kärcher, B., R. Busen, A. Petzold, F. P. Schroder, U. Schumann, and E. J. Jensen (1998), Physicochemistry of aircraft-generated liquid aerosols, soot, and ice particles-2: Comparison with observations and sensitivity studies, J. Geophys. Res., 103(D14), 17,129-17,147.

Knopf, D. A., and T. Koop (2006), Heterogeneous nucleation of ice on surrogates of mineral dust, J. Geophys. Res., 111, D12201, doi:10.1029/ 2005JD006894

Lohmann, U., and K. Diehl (2006), Sensitivity studies of the importance of dust ice nuclei for the indirect aerosol effect on stratiform mixed-phase clouds, J. Atmos. Sci., 63, 968-982.

Lohmann, U., and J. Feichter (2005), Global indirect aerosol effects: A review, Atmos. Chem. Phys., 5, 715-737.

Mangold, A., R. Wagner, H. Saathoff, U. Schurath, C. Giesemann, V. Ebert, M. Kramer, and O. Möhler (2005), Experimental investigation of ice nucleation by different types of aerosols in the aerosol chamber AIDA: Implications to microphysics of cirrus clouds, Meteorol. Z., 14(4), 485497.

Marcolli, C., S. Gedamke, T. Peter, and B. Zobrist (2007), Efficiency of immersion mode ice nucleation on surrogates of mineral dust, Atmos. Chem. Phys., 7, 5081-5091.

Martin, S. T. (2000), Phase transitions of aqueous atmospheric particles, Chem. Rev., 100(9), 3403-3453.

Mason, B. J., and J. Maybank (1958), Ice nucleating properties of some natural mineral dusts, Q. J. R. Meteorol. Soc., 84, 235-241.

Meyers, M. P., P. J. Demott, and W. R. Cotton (1992), New primary ice nucleation parameterization in an explicit cloud model, J. Appl. Meteorol., 31, 708-721.

Middlebrook, A. M., L. T. Iraci, L. S. McNeill, B. G. Koehler, M. A Wilson, O. W. Saastad, M. A. Tolbert, and D. R. Hanson (1993), Fourier transform-infrared studies of thin $\mathrm{H}_{2} \mathrm{SO}_{4} / \mathrm{H}_{2} \mathrm{O}$ films-Formation, wateruptake, and solid-liquid phase-changes, J. Geophys. Res., 98(D11), 20,473-20,481.

Morrison, H., J. A. Curry, and V. I. Khvorostyanov (2005), A new doublemoment microphysics parameterization for application in cloud and climate models. part 1: Description, J. Atmos. Sci., 62, 1665-1677.

Möhler, O., et al. (2006), Efficiency of the deposition mode ice nucleation on mineral dust particles, Atmos. Chem. Phys., 6, 3007-3021.
Murphy, D. M., and T. Koop (2005), Review of the vapour pressures of ice and supercooled water for atmospheric applications, Q. J. R. Meteorol. Soc., 131(608), 1539-1565.

Murray, B. J., D. A. Knopf, and A. K. Bertram (2005), The formation of cubic ice under conditions relevant to Earth's atmosphere, Nature, 434 $202-205$

Murray, B. J., and A. K. Bertram (2006), Formation and stability of cubic ice in water droplets, Phys. Chem. Chem. Phys., 8, 186-192.

Pant, A., M. T. Parsons, and A. K. Bertram (2006), Crystallization of aqueous ammonium sulfate particles internally mixed with soot and kaolinite: Crystallization relative humidities and nucleation rates, J. Phys. Chem. A, 110(28), 8701-8709.

Parsons, M. T., D. A. Knopf, and A. K. Bertram (2004a), Deliquescence and crystallization of ammonium sulfate particles internally mixed with water-soluble organic compounds, J. Phys. Chem. A, 108(52), 11,60011,608 .

Parsons, M. T., J. Mak, S. R. Lipetz, and A. K. Bertram (2004b), Deliquescence of malonic, succinic, glutaric, and adipic acid particles, J. Geophys. Res., 109(D6), D06212, doi:10.1029/2003JD004075.

Prospero, J. M. (1999), Long-range transport of mineral dust in the global atmosphere: Impact of African dust on the environment of the southeastern United States, Proc. Natl. Acad. Sci. U. S. A., 96, 3396-3403.

Pruppacher, H. R., and J. D. Klett (1997), Microphysics of Clouds and Precipitation, Kluwer Academic Publishers, Dordrecht, Netherlands.

Richardson, M. S., et al. (2007), Measurements of heterogeneous ice nuclei in the western United States in springtime and their relation to aerosol characteristics, J. Geophys. Res., 112(D2), D02209, doi:10.1029/ 2006JD007500.

Roberts, P., and J. Hallett (1968), A laboratory study of the ice nucleating properties of some mineral particulates, Q. J. R. Meteorol. Soc., 94, $25-$ 34.

Rogers, D. C., P. J. Demott, and S. M. Kreidenweis (2001), Airborne measurements of tropospheric ice-nucleating aerosol particles in the Arctic spring, J. Geophys. Res., 106(D14), 15,053-15,063.

Salam, A., U. Lohmann, B. Crenna, G. Lesins, P. Klages, D. Rogers, R. Irani, A. MacGillivray, and M. Coffin (2006), Ice nucleation studies of mineral dust particles with a new continuous flow diffusion chamber, Aerosol Sci. Technol., 40, 134-143.

Sassen, K. (2002), Indirect climate forcing over the western US from Asian dust storms, Geophys. Res. Lett., 29(10), 1465, doi:10.1029/ 2001GL014051.

Sassen, K. (2005), Dusty ice clouds over Alaska, Nature, 434, 456

Sassen, K., P. J. DeMott, J. M. Prospero, and M. R. Poellot (2003), Saharan dust storms and indirect aerosol effects on clouds: CRYSTAL-FACE results, Geophys. Res. Lett., 30(12), 1633, doi:10.1029/2003GL017371.

Schuttlefield, J. D., D. Cox, and V. H. Grassian (2007), An investigation of water uptake on clays minerals using ATR-FTIR spectroscopy coupled with quartz crystal microbalance measurements, J. Geophys. Res., 112, D21303, doi:10.1029/2007JD008973.

Toon, O. B. (2003), African dust in Florida clouds, Nature, 424, 623-624.

Twohy, C. H., and M. R. Poellot (2005), Chemical characteristics of ice residual nuclei in anvil cirrus clouds: Evidence for homogeneous and heterogeneous ice formation, Atmos. Chem. Phys., 5, 2289-2297.

Vali, G. (1985), Nucleation Terminology, Bull. Am. Meteorol. Soc., 66(11), $1426-1427$

Vali, G. (1996), Ice nucleation - a review, in Nucleation in Atmospheric Aerosols, edited by M. Kulmala and P. Wagner, pp. 271-279, Pergamon Press, Oxford, UK.

Zimmerman, F., M. Ebert, A. Worringen, L. Schütz, and S. Weinbruch (2007), Environmental scanning electron microscopy (ESEM) as a new technique to determine the ice nucleation capability of individual atmospheric aerosol particles, Atmos. Environ., 41, 8219-8227.

Zuberi, B., A. K. Bertram, C. A. Cassa, L. T. Molina, and M. J. Molina (2002), Heterogeneous nucleation of ice in $\left(\mathrm{NH}_{4}\right)_{2} \mathrm{SO}_{4}-\mathrm{H}_{2} \mathrm{O}$ particles with mineral dust immersions, Geophys. Res. Lett., 29(10), 1504 doi:10.1029/2001GL014289.

A. K. Bertram, S. Cremel, M. L. Eastwood, and C. Gehrke, Department of Chemistry, University of British Columbia, 2036 Main Mall, Vancouver, BC, Canada V6T 1Z1. (bertram@chem.ubc.ca)

E. Girard, Department of Earth and Atmospheric Sciences, University of Quebec at Montreal, P.O. Box 8888, Downtown, Montreal, QC H3C 3P8, Canada. 